\title{
Influence of the Roman Law on Formation of the Romano-Germanic Legal Family
}

\author{
Safia Hamitovna Muhametgalieva ${ }^{1}$, Iskandar Gabdulvalievich Muhametgaliev ${ }^{1} \&$ Valentina Igorevna \\ Kuzmenko ${ }^{1}$ \\ ${ }^{1}$ Kazan Federal University (KFU), Department Yelabuga Institute, Elabuga, Russia \\ Correspondence: Safia Hamitovna Muhametgalieva, Kazan Federal University (KFU), Department \\ Yelabuga Institute, Kazanskaya st., 89, Elabuga, Tatarstan Republic, 423600, Russia.
}

$\begin{array}{lcc}\text { Received: February 28, } 2015 & \text { Accepted: March 20, } 2015 \quad \text { Online Published: April 24, } 2015 \\ \text { doi:10.5539/res.v7n6p186 } & \text { URL: http://dx.doi.org/10.5539/res.v7n6p186 }\end{array}$

\begin{abstract}
Any legal family or national legal system passes the period of its historical formation. The purpose of writing of the work is elaboration of scientific idea of influence of the Roman law on formation of the Romano-Germanic legal family.

Such factors as the period of the great transmigration of peoples, rich heritage of the Roman law, city, local and canon laws, which put a tradition of the written law as the main source, development of university thought, full-scale codification influenced formation and development of the Romano-Germanic legal family.

The goal is achieved by means of the solution of the following main objectives:

-Revealing features and stages of formation of the Romano-Germanic legal family;

-Revealing theoretical aspects of identification of the Roman law in the Romano-Germanic legal family.
\end{abstract}

Keywords: reception of Roman law, Romano-Germanic legal family, formation of the law, codification, glossator school

\section{Introduction}

The Roman lawyers created science of the Roman law which deservedly enjoys authority from antiquity to the present. It was a legal science, the first in the history of mankind, with abstract norms of the secular law. The heritage of the Roman lawyers continues to be used actively in modern society. By means of reception the Roman law both indirectly and directly influenced and influences development of the legislation and legal science. Its influence is traced in various branches of the law-from criminal to the civil one. Terminology, the basic principles of the Roman law are contained in any legal system of the world.

In the last decades the scientific interest in the Roman law increases in different countries of the world. It is connected with transition of economy of a number of the European countries to the market relations.

Among the legal families, existing in the modern world, the Romano-Germanic legal family takes a special place. According to René David, it is "the first family which we meet in the modern world" (David \& Zhoffre-Spinozi, 1998). Yu. A. Tikhomirov notes that "this legal system" is "the most ancient and widely extended in the world" (Tikhomirov, 1996). It should be noted importance of the Romano-Germanic legal family for development of the legal theory and practice in universal scale.

\section{Methods}

In the course of writing of the article the general methods of scientific knowledge were applied: Philosophical categories of essence and phenomenon, form and content, general scientific methods of research (logical analysis and synthesis, induction and deduction, abstraction and ascension from abstract to concrete, system, functional) what allowed the authors to reveal the influence of the Roman legal heritage on the Romano-Germanic legal family.

Specifics of the subject of the work caused the use of legalistic, historical and legal and comparative and legal methods of research. Thus, the legalistic method was used when determining methodological aspects of interaction of the Roman law and the Romano-Germanic legal family. The historical and legal method helped to study the 
historical stages of formation of the Romano-Germanic legal family.

The empirical base of the research was made by domestic and foreign literature on comparative law, by the materials of round tables and scientific and practical conferences on problems of development of legal families and systems of the present.

\section{Results}

The Romano-Germanic legal family is a formed and approved in continental Europe by XII-XVI centuries with use of the Roman legal heritage and united by a community of structure, sources of law and developing in the modern period set of the system-structured elements of the standard, ideological and concrete and practical content of national legal systems, having such characteristics as structuredness, hierarchy and abstractness of norms of the written law.

The Romano-Germanic legal family covers the countries of continental Europe, the most part of the countries of Africa, all countries of Latin America, countries of the East and some others.

It should be noted that originally this system included legal systems of a number of the countries of the European continent which inherited the basic concepts, juridical constructions of the Roman law. The legal systems of such related "Romance" states as France, Holland, Belgium, Spain, Italy belonged to this family. Germany, the influence of law of which on the continental system becomes especially remarkable since the end of XIX and in the first half of the XX century, also belonged to the same group. However, the influence of the German law, which reflected synthesis of the barbarous (German) and Roman law, became so essential that the continental system itself began to be called as the Romano-Germanic legal family.

The continental system of the law extravagated the European continent in its development very quickly. Owing to the influence of the Roman-Spanish legal traditions it was taken by practically all Latin American countries in the XIX century where reception of the French and Roman law was especially deep. According to the contents the term "Romano-Germanic legal family" is more capacious and substantial than "continental legal system". It is necessary to agree with A. Kh. Saidov, who specifies, that the term "Romano-Germanic" was chosen to pay tribute to the joint efforts made at the same time by universities of the Latin and German countries (Saidov, 2000).

Formation of the Romano-Germanic legal family is a long historical process covering several centuries and which began in the VIII-XII centuries. It proceeded evolutionarily and more smoothly than the corresponding processes in the sphere of policy and the state where they quite often took the form of public cataclysms and revolutionary moods. Formation of the Romano-Germanic legal system happened under the influence of actually historical, geographical reasons, the Roman and canon law, barbarous customs and also political and social and economic prerequisites made impact.

The Romano-Germanic legal family passes a long and difficult way in its development.

We will note that the authors, investigating this problematics, in general adhere to the uniform concept of differentiation of formation stages of the considered legal system.

There are two main points of view on the formation process of the Romano-Germanic legal family. According to the first concept the Romano-Germanic legal family "was formed" in the XII-XVI centuries as a result of activities of the leading universities. According to A. Kh. Saidov, the Romano-Germanic legal system was formed on the basis of studying the Roman law at the Italian, French and German universities which created in the XII-XVI centuries the legal science, general for many European countries, on the basis of Institutes of Justinian (Nersesyantsa, 2004). Thus, V. V. Lazarev notes that the Romano-Germanic legal family or a family of the continental law (France, Federal Republic of Germany, Italy, Spain and other countries) has long legal history. It was formed in Europe as a result of efforts of scientists of the European universities who elaborated and developed since the XII century the legal science, general for all, on the basis of codification of the imperator Justinian, adapted for conditions of the contemporary world (Lazarev, 2001). In particular, Jean-Louis Bergel reveals the Romano-Germanic legal system through the category "Romano-Germanic family of legal systems", i.e. legal systems which cornerstone is the Roman law (Bergel, 2000).

According to the second concept the family of the Romano-Germanic law appeared and began to form in the XIII century. Within the offered theory the scientists allocate various stages of formation of the Romano-Germanic legal family which are caused by the historical, socio-political reasons, are characterized by the features of development of the legal theory (e.g. glossator schools) and practice.

R. David, M. N. Marchenko determine the formation stages of the Romano-Germanic legal system as follows (Marchenko, 2001): 
1) VIII-XIII centuries. Lack of any system of law and attempt to synthesize the available norms.

2) XIII-XVIII centuries. Renaissance and studying the Roman law at the universities.

3) XVIII-XX centuries. Distribution of the Romano-Germanic legal system on other continents, the period of full-scale codification.

A. Kh. Saidov, Yu. A. Tikhomirov don't allocate exact stages, characterizing development of the Romano-Germanic legal system in logical interrelation (Tikhomirov, 1996).

The point of view of N. I. Matuzov and A. V. Malko is represented rather interesting. The researchers allocate the following stages:

1) Era of the Roman Empire-XII century AD. Origin of the Roman law and its decline in connection with death of the Roman Empire (476 AD), domination in Europe of archaic ways of the solution of disputes-duels, trials by battle (tests), sorcery, etc., i.e. the actual absence of the law;

2) XIII-XVII centuries. Renaissance of the Roman law, its distribution in Europe and adaptation to new conditions, achievement of independence of the law from the royalty;

3) XVIII-XX centuries. Codification of the law, adoption of Constitutions (in the USA, Poland, France, etc.), emergence of industry codes (The French Civil Code 1804, the German Civil Code 1896), creation of national legal systems (Matuzova \& Malko, 2002).

\section{Discussion}

The first period of formation and development of the Romano-Germanic legal system is chronologically defined by the period, preceding its evolution up to the XIII century. According to the scientists-lawyers, it is the XIII century that is to be considered as "time when from the scientific point of view there a system of the Romano-Germanic law appeared" (Marchenko, 2001). Till this time there was an active process of accumulation of the corresponding material, its generalization and studying, creation of prerequisites and reasons for formation of a uniform system of the Romano-Germanic law. It should be noted that the elements, existing in that period, of which the Romano-Germanic legal family was forming gradually, had character of the common law.

In the territory of the present European countries the norms-customs, "laws" of the German, Nordic and other tribes - laws of barbarians were applied. They were various and motley. Even no attempts to systematize them and generalize were made (Skakun, 2000). From the scientific point of view the system of the Romano-Germanic law appeared in the XIII century. Till this period, beyond all doubt, there were elements, by means of which the system was created, but it was early then to speak about the system (Estévez et al., 2013).

The Romano-Germanic legal family takes its historical and genetic beginning in Ancient Rome. The Roman civilization created a special, unique legal system, which became a basis both for formation of legal systems and for the sectoral legislation. This distinguishes this legal family from all other legal families, existing in the contemporary world. Its main feature consists just in the sources. The historical roots of the continental legal system were formed in legal views and in the law of the Roman Empire (Tikhomirov, 1996, p. 189), (Saidov, 2000, p. 211).

In 476 Rome fell under the invasion of barbarians. In the former territories of the Western Rome the German states began to be formed actively. The Roman legal heritage was taken by the Germans, who formed norms on the basis of use of the classical Roman law. Such law acquired the name "the vulgar Roman law" (Serebrova, 2005, p. 11). This is explained by the fact that during the conquests the Germans were not ready to perceive the highly developed Roman culture fully (Anners, 1994). Among the legal monuments of that time it should be specified: "Lex Romana Visigothorum"-Laws of the Roman Visigoths or 'Breviarum Alaricianum"-Alarikh's Reference book, "Lex Visigothorum Vulgata"-Visigothic law in Vulgate. The stage of formation of the written law began.

Subsequently, when the most part of the territory of East Rome appeared under the power of pawnshops, the Romano-Germanic law also continues to develop.

During the considered period justice was oral; the law had no completeness and stability and existed only formally. Administration of justice was in power of "Strong in power" leader as up to the XIII century the law wasn't taught, the power assumed the right of expression of justice and was identified with orders of the sovereign. In judicial trials, as it is noted in the special sources, the address to supernatural with use of the inquisitional system of proofs dominated. Execution of adjudgements wasn't provided in any way.

Only in the XIII-XVI centuries there were cardinal changes of justice: firstly, the oral process, characteristic of 
the common law, was gradually replaced by the written one; secondly, administration of justice became a matter of lawyers who got university education.

It is important to note that in some countries the process of generalization of local customs took place. Many of urban towns published codification of local customs; these codifications carried the name of statutes. The statutes mainly represented the declarative approval of the common law of earlier period applied in a town and in its trade communities-"a statute is a voluntary accepted norm which comes from a folk custom" (Getman-Pavlova, 2010). The local, town norms of the civil law (in the form of codification of ancient customs or in the form of issue of new municipal statutes) began to appear in autonomous urban towns in Italy in the XI and XII centuries. The town statutes regulate trade and industrial life, criminal justice, university organization, private-law relations. During the same period the code, Digesta and institutions of Justinian and also other sources of the Roman law, adapted for new conditions, were widely used.

It should be noted that discussions, concerning from what time the process of the Roman law in continental Europe begins, still don't cease.

In particular, Yu. A. Tikhomirov specifies that lawyers-researchers and historians conduct the beginning of the Romano-Germanic legal family since the XIII century (Czinkota, 2014). As till this time the law in Europe represented a sum of norms of the common law when the breakdown of the Roman Empire and invasions of barbarians brought customs of particular tribes and nationalities and cult pagan norms with them, the Roman consolidated acts - Code of Justinian, Digesta - remained unclaimed.

A number of researchers, in particular, N. M. Korkunov, Yu. M. Yumashev, \& K. V. Filimonov note that already the XII century can be called a legal century; it in general is represented the beginning of that revival of medieval life and medieval thought which affected the next XIII century especially brightly (Korkunov, 1915). The first acquaintance to the Arab commentators of Aristotle, which was the main incitement to development of scholastic philosophy, belongs to this era; at the end of the XI-at the beginning of the XII century in Western Europe the process of reception of the Roman law began. The Roman law, which consisted in Codification of Justinian, became a source from which the courts and legislators drew both the general fundamental principles and private concrete rules.

In our opinion, owing to the historical, socio-political prerequisites the process of influence of the Roman law on formation of the Romano-Germanic legal system can't be limited to one stage and exact time frame.

Thus, the role of the Roman law is considerably studied by the scientists from the point of view of continuity and influence of the Roman law on formation of the Romano-Germanic legal system. The first serious foundation of systematic literary development of the Roman law was laid by the glossator school which arose in University of Bologna at the beginning of the XII century. The conventional ancestor of the school is considered Irnerius (Vacarius, Varnerius, \& Garnerius, pp. 1085-1125). Also other glossators-Martin, Bulgar, Yakov, Gugo, Platsentin, Azo (Atso), Odofred, Bassian, Aldrik, Akkursy and some others enjoyed huge authority (Muromtsev, 1885). The glossator school reached apotheosis of its development at Azzona Azo (about 1230 died): his glosses and sums enjoyed the greatest authority (Pokrovsky, 1918).

The Roman law is a classical expression of living conditions and conflicts of the society in which the private property dominates. This is what caused a possibility of adaptation of the Roman law to the commodity-money relations developing in a subsoil of medieval Europe. It was the legal science, the first in the history of mankind, with abstract norms of the secular law (Tkachenko, 2006). Codification of Justinian takes a special place. Codification of Justinian "comprised the principles of the public law (jus gentium) clothed in graceful shapes of classical law. Instead of working on creation of new rules, the Italian lawyers should have been started studying law of Justinian to find there an answer to all requirements of contemporary for them public life" (Bogolepov, 1876).

The approaches to studying the law, according to which it was recommended to consider the law not only and even not so much in actually practical as in the academic plan, were developed. Namely - to investigate it both in technical and legal and in broad social aspect, from the point of view of "filling" it as a certain model of the social organization of the principles of humanity, good and justice.

In feudal disunity the university scientists when teaching the law couldn't be based on the local, based on customs, law which, in their opinion, didn't express justice and in fact it wasn't the law. For this reason the Roman law became a basis of teaching the corresponding course at all universities of Europe, having undergone a number of changes.

So, conditionally activities and directions of the university currents can divided as follows: 
1) Glossator school. This school sought to establish the initial sense of the Roman laws. As the result of their work in the XIII century there generalizing Accursius's work appeared which included about 96 thousand of glosses.

To glossators the Roman law was studied (for example, in Ravenna) with the applied purpose: they took only that corresponded to subjective views on justice from the sources. The glossators entered studying the Roman law in pure form, regardless of subjective sense of justice (Berman, 1998).

The historical importance of glossators is that the Roman law was borrowed in the West European states on the basis of the works published by them which were systematizing the separate legal rules in a whole and offered the interpretation corresponding to the time. The role of glossators was expressed precisely by O. S. Ioffe: “. . . this material (works of glossators) had at the same time the great practical importance in the history of the law as reception of the Roman law was made not in full of its texts but only in that their part in what they were subjected to glossing. For court the Roman sources, not supplied with glosses (quidquid non agnoscit glossa, non agnoscit curia)", couldn't have binding force (Ioffe, 2000).

2) Postglossator school. In the XIV century the Roman law was subjected to processing and was systematized so that its norms could be used in practice for pronouncement of legal decisions. The post-glossators created the logical principles, constructions and generalized formulas, put in the Roman private law, at the new level of spiritual and intellectual life of Renaissance. The logical principles and constructions and also terminology of the Roman law can be also characterized as materials of legal culture which was apprehended by the legislation of continental Europe.

3) School of natural law. The universities couldn't pretend to creation of the positive law as weren't authorized to establish norms obligatory for application by practicing lawyers. They didn't possess a possibility of the actual fixing of precepts of law. The scientists, being guided by the Roman texts, sought to find the most just rules and norms. It should be noted that the French scientist R. David paid his attention to unsuitableness of the term "natural law". In his opinion, if to speak about the natural law, there are more bases to consider as that the common law developing historically, gradually, evolutionarily, originating in depth of centuries (David, 1998). The school of the natural law put a person in the centre of the social order, emphasizing his inalienable "natural" rights which are represented universal, uniform for all times and the peoples.

The adherents of the school of natural law emphasize a new role of the law as manifestations of sense. Division of the law into the natural and positive meant recognition of a role of the doctrine in the legal sphere, a necessity of check of the operating (positive) law for compliance to the natural. Thus, apparently, the theoretical construction forms quite certain relation to the law of the government as to a way of expression of the natural law. As a result the law loses a property of sanctity, indisputability, its critical comprehension becomes possible.

In the field of the private law this school didn't refuse of the decisions formulated by the post glossators. It only demanded that norms of the Roman law should be applied where it is pertinent, and in that measure in what they don't contradict sense, justice, requirements of society.

In the sphere of public regulation, the Roman law couldn't serve as a sample. The school of the natural law offered the models of constitution, administrative, criminal law brought out of "sense", expressing the natural human rights, guaranteeing a personal freedom.

The essential changes happened also in judicial trial regulation. With refusal of an inquisitional form of the trial in continental Europe a new rational trial on an example of the canon law was entered.

The law taught judges as, being guided by its provisions, they must resolve one or another question. The law established norms, by which judges must be guided in their professional and public activities (Fitzpatrick, 2001).

In process of development of the European society not only idea of the law but also the attitude towards it changed. In university programmes and courses the priority attitude towards the Roman law was gradually replaced by aspiration to formulate such principles of the law which would be expression not only the academic but also rationalistic beginnings. As a result in legal practice deep theoretical constructions were put.

Achievements of science of Renaissance became a necessary condition and a basis for genesis of classical science of Modern Age.

However, it can't be overestimated development of the positive law in the period of the Middle Ages. Thus, A. I. Kosarev specifies that "in the period of the late Middle Ages an adaptation of old legal institutes to regulation of the arising relations occurs. At the same time the former underdevelopment of the law, expressed in feudalism, causality, etc. is overcome. Finally the primary branches of the law are formed, the partial codifications are 
carried out, the general concepts are developed, the scope of the law is extended. It is observed, however, other extreme- excessively broad control of the right of the public relations. It manifested, for example, in a shop regulation" (Kosarev, 2002).

\section{Conclusion}

The Roman law is a finished law of simple commodity production, therefore, of the pre-capitalistic; this law, however, comprises the most part of legal relations, i.e. what citizens needed during emergence of the cities and what they didn't find in the local common law.

Within reception of the Roman law a process of studying the conceptual fund, internal logic, legal technique of the Roman law occurred actively. A basis for reception, first of all, became economic prerequisites. This is development of trade, crafts, growth of the cities. The feudal norms, which are based on the ideas of vassalage and patrimonial jurisdiction, which took roots in the village, didn't correspond to the principles of self-government of the free, "free-and-easy" cities. During this historical era, sated with acute social contradictions, the mankind in general moved ahead in development of productive forces, material and spiritual culture in comparison with the previous history period.

The objective need for other legal regulation ripened, another system of standard and legal regulation, constructed on ideas of formal equality and independence of participants of the market relations, was required. Such system, answering to the called ideas most of all the Roman law appeared. Except the economic reasons, there were also sociocultural prerequisites of loan of the Roman law by Europe. There was an active development of education, art, culture that paved the way for perception of the Roman legal concepts.

Thus, Western Europe apprehended the law which initially had strict formality and needed professionals for the application. These signs of the Roman law gained still bigger importance owing to a way of theoretical reception of the Roman law. However, O. Spengler says about affectation of such develop ment what defines specifics of the western legal thinking: "Instead of receiving them (concepts of the law) from the steady and strict custom of public and economic existence, they prematurely and excessively abstract from the Latin manuscripts. The West European lawyer becomes a philologist, and practical experience is substituted for gelerter experience of actual logical decomposition and connection of the legal concepts, based entirely on itself"' (Spengler, 1998).

Reception of the Roman law led to that in the period of the Middle Ages the legal systems of the European countries - their legal doctrine, legal technique - gained a certain similarity.

Thus, finishing consideration of the first stage of formation of the Romano-Germanic legal system, we will note that during the period since the VIII century-till the XI century the common law was applied, the justice system was based on "the power of the leader". Since the XI century reception of the Roman law originates in the countries of continental Europe. To the XIII century in in Europe a necessity of studying and development and also of formal fixing of precepts of law ripened for comprehensive regulation of the public relations, what is caused by such social and economic prerequisites as feudal disunity, formation of the centralized states.

The adherents of the school of natural law emphasize a new role of the law as manifestations of sense. Division of the law into the natural and positive meant recognition of a role of the doctrine in the legal sphere, a necessity of check of the operating (positive) law for compliance to the natural. Thus, apparently, the theoretical construction forms quite certain relation to the law of the government as to a way of expression of the natural law. As a result the law loses a property of sanctity, indisputability, its critical comprehension becoms possible.

In the field of the private law this school didn't refuse of the decisions formulated by the postglossators. It only demanded that norms of the Roman law should be applied where it is pertinent, and in that measure in what they don't contradict sense, justice, requirements of society.

In the sphere of public regulation, the Roman law couldn't serve as a sample. The school of the natural law offered the models of constitution, administrative, criminal law brought out of "sense", expressing the natural human rights, guaranteeing a personal freedom.

The essential changes happened also in judicial trial regulation. With refusal of an inquisitional form of the trial in continental Europe a new rational trial on an example of the canon law was entered.

The law taught judges as, being guided by its provisions, they must resolve one or another question. The law established norms, by which judges must be guided in their professional and public activities (Fitzpatrick, 2001).

In process of development of the European society not only idea of the law but also the attitude towards it changed. In university programmes and courses the priority attitude towards the Roman law was gradually replaced by aspiration to formulate such principles of the law which would be expression not only the academic 
but also rationalistic beginnings. As a result in legal practice deep theoretical constructions were put.

Achievements of science of Renaissance became a necessary condition and a basis for genesis of classical science of Modern Age.

However, it can't be overestimated development of the positive law in the period of the Middle Ages. Thus, A. I. Kosarev specifies that "in the period of the late Middle Ages an adaptation of old legal institutes to regulation of the arising relations occurs. At the same time the former underdevelopment of the law, expressed in feudalism, causality, etc. is overcome. Finally the primary branches of the law are formed, the partial codifications are carried out, the general concepts are developed, the scope of the law is extended. It is observed, however, other extreme- excessively broad control of the right of the public relations. It manifested, for example, in the shop regulation" (Kosarev, 2002).

\section{Acknowledgments}

The work is performed according to the Russian Government Program of Competitive Growth of Kazan Federal University.

\section{References}

Anners, E. (1994). History of the European law / Institute of Europe. Moscow: Science.

Berman, H. (1998). The western tradition of law. Formation era. Moscow: Publishing house of MSU.

Berzhel, J. (2000). General theory of law. Moscow.

Bogolepov, N. (1876). Importance of public civil law (jus gentium) in the Roman classical law. Moscow: Print. of Grachev and Co.

Czinkota, M., \& Skuba, Ch. (2014, October). Contextual analysis of legal systems and their impact on trade and foreign direct investment. Original Research Article. Journal of Business Research, 10(67), 2207-2211.

David, R., \& Zhoffre-Spinozi, C. (1998). Main legal systems of the present. Moscow: International relations.

Dyachek, T. (2008). Peculiar features of the western law as a result of reception of the Roman law in the West. History of State and law, 2, 33-34.

Estévez, E., Rachitskiy, M., \& Rodríguez, C. (2013, July). Is perception of the mainstream legal system homogeneous across ethnic groups? Original Research Article The European Journal of Psychology Applied to Legal Context, 2(5), 155-161.

Fitzpatrick, P. (2001). Law: Imposition, Reception, and Colonial. International Encyclopedia of the Social \& Behavioral Sciences.

Getman-Pavlova, I. (2010). Sources of science of the international private law: Glossator school. International public and private law, 2, 17-23.

Ioffe, O. (2000). Chosen works on civil law. From history of civil thought. Civil legal relationship. Criticism of the theory of "economic law". Moscow: Statute.

Korkunov, N. (1915). History of legal philosophy. Saint Petersburg: Print. of M. M. Stasyulevich.

Kosarev, A. (2002). History of state and law of foreign countries. Moscow: Norma-Infra-M.

Lazarev, V. (2001). General theory of law and state: Textbook. Moscow.

Marchenko, M. (2001). Problems of the theory of state and law. Moscow: David R. Op. Cit.

Matuzov, N., \& Malko, A. (2002). Theory of State and law: A course of lectures. Moscow: Yurist.

Muromtsev, S. (1885). Reception of the Roman law in the West. Moscow: Print. of A.I. Mamontov and Co.

Nersesyants et al. (Eds.) (2004). Problems of the general theory of law and state. In Textbook for higher education institutions. Moscow: Norm.

Pokrovsky, I. (1918). History of the Roman law. Petrograd.

Saidov, A. (2000). Comparative jurisprudence (main legal systems of the present). Moscow.

Serebrova, S. (2005). General-theoretical bases of formation of the European legal system, synopsis of a thesis, Moscow.

Skakun, O. (2000). Theory of State and law: Textbook. Kharkov: Konsum; University of internal Affairs.

Spengler, O. (1998). The Decline of Europe (Vol. 2). Moscow: Thought. 
Tikhomirov, Yu. (1996). Course of comparative jurisprudence. Moscow: Norm.

Tkachenko, S. (2006). Reception of the Roman law: Questions of the theory and history (dissertation). Moscow. Vasilyev, A. (2010). Doctrine of glossators as law source in medieval Europe. History of state and law, 3, 38.

Yumashev, Yu., \& Filimonov, K. (2009). European Union and international private law: Sources of the European private law. Right, 1, 3-20.

\section{Copyrights}

Copyright for this article is retained by the author(s), with first publication rights granted to the journal.

This is an open-access article distributed under the terms and conditions of the Creative Commons Attribution license (http://creativecommons.org/licenses/by/3.0/). 